\title{
Determination of plasmin (alkaline milk proteinase) and chymosin in milk products by the ELISA assay
}

\author{
J.C. COLLIN *, P. COMPAGNONE *, I. RYBA ** and A. BAER ** \\ * INRA, BP $n^{\circ} 94,39800$ Poligny, France \\ ** Station Fédérale de Recherches Laitières, 3097 Liebefeld, Switzerland
}

\begin{abstract}
Summary
The ELISA assay was used to measure the complex plasminogen-plasmin as well as chymosin in milk products. The results showed that plasmin concentration was slightly higher than the corresponding enzymatic activity, which could be explained by the blockage of several active sites by inhibitors or caseins. Measurement of chymosin in a St Paulin type cheese and a hard cheese "Comté " showed evidence for residual activity of chymosin in both curds. However, active enzyme was found only in the "St Paulin » whey. Therefore, the heat stability of chymosin is enhanced when bound to caseins and some activity may subsist in hard cheeses.
\end{abstract}

\section{Résumé}

Dosage de la plasmine et de la chymosine dans les produits laitiers par la méthode ELISA

La méthode immunologique ELISA a été appliquée au dosage du complexe plasminogène-plasmine ainsi que de la chymosine dans les produits laitiers. Les résultats montrent que la concentration en plasmine est légèrement supérieure à l'activité enzymatique correspondante, ce qui peut s'expliquer par un blocage d'une partie des sites actifs de l'enzyme soit par des inhibiteurs soit par les caséines. Le dosage de la chymosine dans un fromage de type Saint-Paulin et un fromage à pâte cuite pressée "Comté " a mis en évidence une activité résiduelle de la chymosine dans les deux caillés. Par contre, seul le lactosérum de fromage Saint-Paulin possédait encore de la chymosine active. Cela montre que la stabilité de l'enzyme liée aux caséines est accrue et qu'une certaine activité peut subsister dans les fromages à pâte cuite.

\section{Introduction}

Quantitative determination of proteolytic enzymes in milk products is important for a better understanding of the biochemical processes which occur during cheese ripening and conservation. Coagulating enzymes as well as heat 
resistant plasmin (alkaline milk proteinase) may play an important role in the milk industry. As the enzymes encountered in milk products are partially bound to their substrate, it is difficult to determine their activity without performing an extraction, as it is usually done, for example, to measure chymosin activity in cheese.

In this short communication we describe an immunological method (ELISA) to measure quantitatively and specifically free and bound plasmin and its zymogen, plasminogen as well as chymosin. The results are compared with the enzymatic determination of plasmin activity.

\section{Material and methods}

\section{A. Purification of bovine plasminogen}

Bovine plasminogen was purified by affinity chromatography as described by Deutsch and Mertz (1970), using fresh blood plasma. The protein thus obtained was freed from immunoglobulin contamination by gel filtration on Bio-Gel P-100. Plasminogen was activated to plasmin with urokinase according to Castellino and Sodetz (1976).

\section{B. Samples preparation}

Milk samples were prepared from fresh milk or lyophilized milk powder for the determination of the enzymatic activity of plasmin, as described by Richardson and Pearce (1981) (previous experiments showed that lyophilization of raw milk did not alter the enzymatic activity). When necessary, caseins were separated by isoelectric precipitation. After centrifugation, they were diluted in a solution of $0.4 \mathrm{M}$ sodium-citrate (SC).

\section{ELISA assay}

Antibodies, obtained in rabbits, were diluted $1 / 200$ in $0.1 \mathrm{M}$ phosphate buffer, $\mathrm{pH}$ 7.2. One hundred microliter of this solution were added to each well of a Nunc plastic plate and incubated at $37^{\circ} \mathrm{C}$ for 90 minutes. The wells were then washed three times with PBS containing $0.05 \%$ of Tween-20 (PBSTween). Antigen solution diluted $1 / 25$ to $1 / 400$ with SC-Tween were added to the wells $(100 \mu \mathrm{l}$ each) and incubated as described above. After washing three times, an antigen-alkaline phosphatase conjugate, diluted 1/40 with PBSTween, was added. A further incubation-washing cycle was performed. A solution of $1 \mathrm{mg} / \mathrm{ml}$ of p-nitrophenylphosphate disodium salt solubilized in $1.0 \mathrm{M}$ diethanolamin- $\mathrm{HCl}$ buffer, $\mathrm{pH} 9.8$, containing $0.01 \%$ of $\mathrm{MgCl}_{2}, 0.05 \%$ AcZn and $0.05 \%$ thimerosal (w/v) was added to each well. After 30 minutes the enzymatic reaction was stopped by adding $20 \mu \mathrm{l}$ of $6.0 \mathrm{M} \mathrm{NaOH}$ and the intensity of the reaction determined by measuring the absorbance in each well at $405 \mathrm{~nm}$.

\section{Determination of plasmin activity}

Plasmin activity was determined using the fluorimetric method described by Richardson and Pearce (1981). The aminomethyl coumarin peptide (Suc- 
Ala-Phe-Lys-AMC) was purchased from Bachem (Bubendorf, Switzerland). The specific activity of the enzyme was determined by active site titration according to the method described by Chase and Shaw (1970).

\section{Results and discussion}

\section{A. Immunological quantification and enzymatic activity of plasmin and plasminogen in raw milk}

Table 1 shows the results obtained with 9 individual cow milk samples. The results of the enzymatic determinations of plasmin and plasminogen are in good agreement with the values published by Richardson and Pearce (1981): 140 to $730 \mathrm{ng} / \mathrm{ml}$ of plasmin and 550 to $2750 \mathrm{ng} / \mathrm{ml}$ of plasminogen. The values obtained by the ELISA assay are about 2.5 times higher than the enzymatic values. These discrepancies could be due to the fact that several active sites of the enzyme are occupied by inhibitors, or are still bound to casein whereas the rest of the molecule of the antigen can still be recognized by the antibody. It is also possible that the sample preparation may alter the enzymatic activity without modifying the antigenic structure. The activation of plasminogen to plasmin by urokinase may also be partially hindered by the presence of caseins. If the titration of the purified antigen has not been somewhat overestimated, it seems that the immunological method can determine the total amount of plasminogen and plasmin in milk.

\section{TABLE 1}

Comparison of enzymatic and immunological measurements of plasminogen-plasmin activity in the milks of 9 individual cows.

The results are expressed in $\mathrm{ng}$ per $\mathrm{ml}$

Comparaison des méthodes enzymatique et immunologique pour mesurer l'activité du complexe plasminogène-plasmine dans le lait individuel de 9 vaches. Résultats exprimés en $\mathrm{ng} / \mathrm{ml}$

\begin{tabular}{c|c|c|c}
\hline \multirow{2}{*}{ Sample Nr. } & \multicolumn{2}{|c|}{ Enzymatic activity } & \multirow{2}{*}{ ELISA } \\
\cline { 2 - 3 } & Plasmin & $\begin{array}{c}\text { Plasmin } \\
\text { Plasminogen }\end{array}$ & \\
\hline \multirow{2}{*}{1} & 192 & 1650 & 4277 \\
2 & 469 & 1400 & 4756 \\
3 & 231 & 953 & 2679 \\
4 & 110 & 1200 & 2644 \\
6 & 475 & 1240 & 3250 \\
7 & 203 & 1300 & 4370 \\
8 & 300 & 1140 & 3522 \\
9 & 155 & 1850 & 2739 \\
\hline \multirow{2}{*}{ Mean Val. } & 257 & 1320 & 4739 \\
\hline
\end{tabular}




\section{B. Quantification of plasmin + plasminogen and chymosin in cheese}

The amount of plasmin and plasminogen bound to the curd or present in the whey was determined in two types of cheeses : one hard cheese "Comté " heated to $56{ }^{\circ} \mathrm{C}$ for 40 minutes and one St Paulin type cheese heated to $33^{\circ} \mathrm{C}$. Table 2 shows the results obtained in raw milk, whey and in the curd, 20 hours after manufacture. The distribution of plasmin and plasminogen is nearly the same in both cheeses since 85 to $90 \%$ of the enzyme are bound to the curd, as previously noted by CASEY et al. (1987). These results are in agreement with the analyses of the enzymatic activity determined in various types of Swiss hard cheeses (BAER, unpublished data). On the contrary they do not confirm the data obtained by BENSLIMANE (1986), who detected almost no activity in "Comté » cheese. Titration of chymosin shows that the ratio of the concentration of the enzyme found in the curd compared to the amount added to the milk is almost the same in both types of cheeses. However the concentration of chymosin determined in the whey St Paulin cheese is much higher than in "Comté » cheese which was heated at higher temperature.

\section{TABLE 2}

Percentage of the amount of enzyme (measured by ELISA technique) present (plasmin + plasminogen) or added (chymosin) in milk recovered in curd and whey for two cheeses of different types (Comté and St Paulin)

Pourcentage d'enzymes (mesuré par la technique ELISA) présente (plasmine + plasminogène) ou ajoutée (chymosine) dans le lait, récupéré dans le caillé ou le lactosérum pour deux types de fromages

(Comté, Saint-Paulin)

\begin{tabular}{l|c|c|c}
\hline & & $\begin{array}{c}\text { Plasmin } \\
+ \text { plasminogen }\end{array}$ & Chymosin \\
\hline Making of hard cheese (Comté) & $\begin{array}{c}\text { curd } \\
\text { whey }\end{array}$ & $\begin{array}{l}90 \% \\
10 \%\end{array}$ & $\begin{array}{r}18 \% \\
<10 \%\end{array}$ \\
\hline Making of St Paulin type cheese & curd & $88 \%$ & $20 \%$ \\
& whey & $12 \%$ & $80 \%$ \\
\hline
\end{tabular}

These results may indicate that the enzyme is immunologically heat resistant when bound to its substrate, as previously described by ANDRÉn et al. (1983) who demonstrated a close relationship between the enzymatic activity of chymosin and its immunological response. Thus it seems that the titration by the ELISA assay of chymosin in cheese reflects its enzymatic activity. These results indicate that a non negligible chymosin activity still remains in hard cheeses, as suggested by Collin et al. (1987) who proposed that the proteolysis of casein $\alpha_{\mathrm{sl}}$ in "Comté " cheese may be due to chymosin activity. However these results should be confirmed. 


\section{Conclusions}

The results presented in this short communication indicate that the ELISA assay could be adapted to the measurement of other milk enzymes. However the data presented here must first be confirmed by further analyses. It may also be possible to differentiate plasmin from plasminogen using monoclonal antibodies.

Reçu le 30 novembre 1987. Accepté pour publication le 11 décembre 1987.

\section{References}

Andren A., De Koning P.J., Bjorck L., 1983. Changes in immunologically and catalytically active sites of chymosin, bovine pepsin and porcine pepsin. Neth. Milk Dairy J., 37, 11-20.

Benslimane S., 1986. Variations de l'activité de la plasmine et du plasminogène dans les laits de vaches montbéliardes et dans les fromages de type Comté. Thèse de doctorat $3^{\mathrm{e}}$ cycle, Université de Besançon.

Casey M., Gruskownjak J., Furst M., 1987. Die Bedeutung von Plasmin bei der Reifung von Greyerzer-Käse. Schweiz. Milchw. Forsch., 16, 21-24.

Castellino F., Sodetz J., 1976. Rabbit Plasminogen and Plasmin Isozymes. In: Methods in Enzymology, Vol. 45, Proteolytic enzymes. Part B, Lorand L. ed., Academic Press, New York, 273-286.

Chase T. Jr., Shaw E., 1970. Titration of Trypsin, Plasmin and Thrombin with p-Nitrophenyl p'Guanidinobenzoate HCl. In : Methods in Enzymology, Vol. 19: Proteolytic enzymes. Perlmann G.E. \& Lorand L. ed., Academic Press, New York, 20-27.

Collin J.C., Berdague J.L., Dognin-Bergeret M., Grappin R., 1987. Affinage et qualité du Gruyère de Comté. IV. Etude de la protéolyse. Lait, 67 (3), 299-318.

Deutsch D.G., Mertz E.T., 1970. Plasminogen : Purification from human plasma by affinity chromatography. Science, 170, 1095-1096.

Richardson B.C., Pearce K.N., 1981. The determination of plasmin in dairy products. N.Z.J. Dairy Sci. Technol., 16, 209-220. 